\title{
Fibroblast Growth Factor 21: A Novel Metabolic Regulator With Potential Therapeutic Properties in Obesity/Type 2 Diabetes Mellitus
}

\author{
I. DOSTÁLOVÁ ${ }^{1}$, D. HALUZÍKOVÁ ${ }^{1,2}$, M. HALUZÍK ${ }^{1}$ \\ ${ }^{1}$ Third Department of Medicine and ${ }^{2}$ Department of Sports Medicine, First Faculty of Medicine and \\ General University Hospital, Charles University, Prague, Czech Republic
}

Received May 7, 2008

Accepted August 4, 2008

\begin{abstract}
Summary
Fibroblast growth factor 21 (FGF21) is a novel metabolic regulator produced primarily by the liver that exerts potent antidiabetic and lipid-lowering effects in animal models of obesity and type 2 diabetes mellitus. This hormone contributes to body weight regulation and is strongly involved in the response to nutritional deprivation and ketogenic state in mice. The principal sites of metabolic actions of FGF21 are adipose tissue, liver and pancreas. Experimental studies have shown marked improvements in diabetes compensation and dyslipidemia after FGF21 administration in diabetic mice and primates. Positive metabolic actions of FGF21 without the presence of apparent side effects make this factor a hot candidate to treat type 2 diabetes and accompanying metabolic diseases. The aim of this review is to summarize the current knowledge about the metabolic effects of FGF21 including some preliminary data on changes of its levels in humans with a special emphasis on its therapeutic potential in type 2 diabetes mellitus.
\end{abstract}

\section{Key words}

Fibroblast growth factor 21 • Fasting • Obesity • Type 2 diabetes - Peroxisome proliferator-activated receptor $\bullet$ Glucose uptake

\section{Corresponding author}

Martin Haluzík, MD, DSc., Third Department of Medicine, First Faculty of Medicine, Charles University, U Nemocnice 1, 12808 Prague 2, Czech Republic. E-mail: mhalu@lf1.cuni.cz

\section{Introduction}

Rapidly increasing prevalence of obesity and its comorbidities commonly referred to as metabolic or insulin resistance syndrome in virtually all developed countries worldwide has stimulated an intensive research exploring the etiopathogenesis of these diseases and the possibilities of its prevention and/or treatment. Adipose tissue is now recognized as an important endocrine organ producing numerous factors involved in energy homeostasis and metabolic regulations (Haluzík et al. 2004, Havel 2002, Housa et al. 2006). In addition to the adipose tissue-derived hormones, also the muscle- and the liver-produced factors are intensively studied as potential regulators of energy homeostasis. Fibroblast growth factor-21 (FGF21) produced predominantly by the liver and, to a lesser extent, also by adipose tissue, represents an example of hepato-adipokine with recently discovered effects on glucose and lipid homeostasis. Positive metabolic effects observed after FGF21 administration in diabetic rodents and monkeys make it an interesting candidate for novel therapeutic agent to treat patients with obesity, type 2 diabetes mellitus and/or other features of metabolic syndrome.

\section{Family of fibroblast growth factors}

Fibroblast growth factors (FGFs) are hormonal factors with diverse biological functions. Human FGF family includes 22 members that are divided into seven subfamilies based on phylogeny and sequence identity (Ornitz and Itoh 2001, Itoh and Ornitz 2004). While most of FGFs act as local regulators of cell growth and differentiation, recent studies indicated that FGF19 subfamily members including FGF15/19, FGF21 and FGF23 exert important metabolic effects by an endocrine fashion. 
The members of FGF19 subfamily regulate diverse physiological processes that are not affected by classical FGFs. The wide variety of metabolic activities of these endocrine factors include the regulation of the bile acid, carbohydrate and lipid metabolism as well as phosphate, calcium and vitamin D homeostasis (Tomlinson et al. 2002, Holt et al. 2003, Shimada et al. 2004, Kharitonenkov et al. 2005, Inagaki et al. 2005, Lundasen et al. 2006).

FGF21 was originally isolated from mouse embryos. FGF21 mRNA was most abundantly expressed in the liver, and to lesser extent in the thymus (Nishimura et al. 2000). Human FGF21 is highly identical (approximately $75 \%$ amino acid identity) to mouse FGF21. Among human FGF family members, FGF21 is the most similar (approximately $35 \%$ amino acid identity) to FGF19 (Nishimura et al. 2000). FGF21 is free of the proliferative and tumorigenic effects (Kharitonenkov et al. 2005, Huang et al. 2006, Wente et al. 2006) that are typical for majority of the members of FGF family (Ornitz and Itoh 2001, Nicholes et al. 2002, Eswarakumar et al. 2005).

\section{Special features of FGF21 signaling}

FGFs exert their biological actions by at least five distinct subfamilies of high-affinity FGF receptors (FGFRs) that belong to a family of tyrosine kinase receptors (Mohammadi et al. 2005). Activation of the FGFRs induces stimulation of divergent downstream pathways mediated by FRS-2, MAPK, SHP-2, PI3K and p $70^{\mathrm{S} 6 \mathrm{~K}}$, Raf, Stat and other signaling molecules (Pelech et al. 1986, Carballada et al. 2001, Deo et al. 2002, Kontaridis et al. 2002).

FGF21 is a typical FGF molecule with respect to its ability to stimulate FGFR substrate $2 \alpha$ (FRS2 $\alpha$ ) phosphorylation and activation of ERK1/2 and Akt signaling pathways (Ibrahimi et al. 2004, Kharitonenkov et al. 2005, Mohammadi et al. 2005, Zhang et al. 2006). However, efforts to demonstrate a direct interaction between FGFRs and FGF21 have failed so far (Kharitonenkov et al. 2005). This observation suggested that a cofactor(s) might be necessary for FGF21 to activate FGF signaling in the tissue. $\beta$ Klotho, a homologous single-pass transmembrane protein that binds to specific FGFRs, was identified as a cofactor essential for FGF21 activity (Ogawa et al. 2007, Suzuki et al. 2008). $\beta$ Klotho brings about binding affinity that is just sufficient to produce a metabolic but not mitogenic response. The expression of $\beta$ Klotho, in combination with particular FGFR isoforms, determines the tissuespecific metabolic activities of FGF21 (Kurosu et al. 2007). $\beta$ Klotho is expressed in adipose tissue, liver, and pancreas (Ito et al. 2000) and thus the major actions of FGF21 are located to these tissues. Cells lacking $\beta$ Klotho do not respond to FGF21 and the introduction of $\beta$ Klotho to these cells confers FGF21-responsiveness and recapitulates the entire scope of FGF21 signaling observed in naturally responsive cells (Kharitonenkov et al. 2007).

Another important regulatory factor of FGF21FGFR binding and dimerization is heparan sulfate (Mohammadi et al. 2005). In contrast to other FGFs, which require heparan sulfate for high affinity receptor binding and activation, FGF21 binds heparan sulfate with low affinity (Goetz et al. 2007). The weak heparan sulfate binding affinity keeps FGF21 from being captured in extracellular matrices and thus to function as an endocrine factor (Mohammadi et al. 2005). In addition, FGF21 contains intramolecular disulfide bonds, which may increase its stability in plasma and allow it to function as a hormone (Harmer et al. 2004).

\section{Hepatic action of FGF21}

Hepatic expression and circulating levels of FGF21 in mice were strongly induced by fasting (12-24 hours) and were rapidly suppressed by refeeding (Badman et al. 2007, Inagaki et al. 2007, Lundasen et al. 2007). In fact, the expression of FGF 21 in the liver was very low in the fed state. FGF21 secreted upon fasting from the liver then acted on adipose tissue to induce metabolic adaptation to fasting. Specifically, FGF21 stimulated lipolysis in adipocytes with subsequent conversion of released fatty acids to ketones in the liver (Badman et al. 2007, Inagaki et al. 2007). In the study comparing FGF21 overexpressing mice with wild-type animals FGF21 overexpression reduced physical activity and promoted torpor, a short-term hibernation-like state of regulated hypothermia that conserves energy in small mammals (Inagaki et al. 2007).

FGF21 was markedly induced in the liver of ketogenic diet-fed mice (78.9 \% fat, $9.5 \%$ protein, $0.76 \%$ carbohydrate) compared with animals fed F6 rodent diet $(6.5 \%$ fat, $24.8 \%$ protein, $39.7 \%$ carbohydrate). The in vivo suppression of hepatic FGF21 expression in ketogenic diet-fed mice with shRNAexpressing adenovirus caused fatty liver, lipemia, and reduced serum ketones. These effects were at least in part mediated by altered expression of the key genes 
governing lipid and ketone metabolism. Hence, the induction of FGF21 was required for the normal activation of hepatic lipid oxidation, triglyceride clearance, and ketogenesis in response to nutritional challenges (Badman et al. 2007).

Multiple findings have indicated that the expression of FGF21 is at least in part downstream of peroxisome proliferator-activated receptor- $\alpha$ (PPAR $\alpha$ ) (Badman et al. 2007, Inagaki et al. 2007, Lundasen et al. 2007). Treatment of mice and human primary hepatocytes with the PPAR $\alpha$ agonist Wy-14,643 markedly induced hepatic mRNA expression of FGF21 (Lundasen et al. 2007). In contrast, FGF21 mRNA was low in PPAR $\alpha$-deficient mice, and 24-h fasting or treatment with $\mathrm{Wy}-14,643$ in these mice did not change its expression. Obese leptin-deficient $o b / o b$ mice with markedly increased hepatic PPAR $\alpha$ levels displayed a 12-fold increased hepatic FGF21 mRNA levels (Memon et al. 2000). Tentative PPARa responsive elements were present in the promoter regions of both mouse and human FGF21 genes (Lundasen et al. 2007).

Stimulation of PPAR $\alpha$ receptors by its exogenous ligands fibrates and FGF21 administration exert several similar metabolic effects. For example, both fibrates and FGF21 administration lowered LDLcholesterol, raised HDL-cholesterol, and improved insulin sensitivity in dyslipidemic rhesus monkeys (Winegar et al. 2001, Kharitonenkov et al. 2007). Furthermore, both PPAR $\alpha$ agonists and FGF21 prevented diet-induced obesity and enhanced insulin sensitivity in rodents (Guerre-Millo et al. 2000, Chou et al. 2002, Kharitonenkov et al. 2005). These overlapping effects suggest that FGF21 contributes to many of the actions of PPAR $\alpha$ agonists. The finding that FGF21 is induced by PPAR $\alpha$ in human hepatocytes raises the intriguing possibility that FGF21 mediates some of the therapeutic actions of the PPAR $\alpha$ agonists - fibrates - that are used as hypolipidemic drugs in humans.

\section{Actions of FGF21 in adipose tissue}

Although liver is a candidate for the paracrine and autocrine actions of FGF21, the most dramatic effects of FGF21 have been found in adipose tissue where neither FGF21 nor FGFR4 are significantly expressed compared to high expression in the liver (Kharitonenkov et al. 2005, Moyers et al. 2007).

FGF21 is a potent stimulator of glucose uptake in mouse 3T3-L1 adipocytes as well as in differentiated human adipocytes (Kharitonenkov et al. 2005). The 72-h combined treatment of 3T3-L1 adipocytes with FGF21 and the PPAR- $\gamma$ agonist rosiglitazone in markedly increased the expression of the GLUT1 glucose transporter and synergistically stimulated glucose transport (Moyers et al. 2007). Recent studies have shown that FGF21 gene is in addition to its stimulation by PPAR $\alpha$ a direct target gene of PPAR $\gamma$ (Wang et al. 2008).

FGF21 effects are insulin-independent and additive to insulin-induced metabolic effects. While insulin works in a rapid manner increasing glucose uptake within minutes, FGF21 activity is very likely mediated through the changes in gene expression. FGF21 stimulatory effect on glucose uptake in adipocytes thus occurs as late as within several hours. In contrast to insulin, which functions through GLUT4 translocation from the intracellular pool to plasma membrane (Shepherd and Kahn 1999), FGF21 appears to upregulate the cellular GLUT1 expression (Kharitonenkov et al. 2005, Ogawa et al. 2007).

FGF21-overexpressing transgenic mice were resistant to diet-induced obesity. The administration of FGF21 to obese leptin-deficient $o b / o b$ and leptin receptor-deficient $d b / d b$ mice and obese ZDF rats significantly lowered blood glucose and triglycerides, decreased fasting insulin levels and improved glucose clearance during an oral glucose tolerance test. FGF21 did not affect food intake or body weight/composition of diabetic or lean mice and rats over the course of 2 weeks of administration. Importantly, FGF21 did not induce mitogenicity, hypoglycemia, or weight gain at any dose tested in diabetic or healthy animals or when overexpressed in transgenic mice (Kharitonenkov et al. 2005).

The administration of FGF21 to diabetic rhesus monkeys for 6 weeks dramatically reduced fasting plasma glucose, fructosamine, triglyceride, insulin and glucagone levels. Importantly, hypoglycemia was not observed during the study despite of significant glucose-lowering effects. FGF21 administration also significantly lowered LDL-cholesterol and increased HDL-cholesterol and, in contrast to mice (Kharitonenkov et al. 2005), slightly but significantly decreased body weight (Kharitonenkov et al. 2007).

\section{Action of FGF21 in pancreas}

FGF21 was detected in human, rat and mouse pancreatic islets as well as in purified rat $\beta$-cells and INS-1E cells (Wente et al. 2006). In pancreatic islets 
isolated from healthy rats, FGF21 increased insulin mRNA and protein levels but did not potentiate glucoseinduced insulin secretion. In islets isolated from diabetic rodents, FGF21 treatment increased islet insulin content and glucose-induced insulin secretion. Short-term treatment of normal or diabetic $d b / d b$ mice with FGF21 lowered plasma insulin levels and improved glucose clearance during oral glucose tolerance test. The ability of FGF21 to increase insulin biosynthesis and promote $\beta$-cell survival without inducing mitogenicity resulted in a dramatic reduction in glucose levels and increased number of islets and $\beta$-cells in $d b / d b$ mice after long-term (constant infusion for 8 weeks) administration of FGF21 (Wente et al. 2006).

FGF21 production and secretion might be related to the metabolic status of the $\beta$-cells. Because FGF21 has a short half-life (Kharitonenkov et al. 2005), local release of FGF21 during high metabolic demand could represent a physiologically important mechanism to maintain $\beta$-cell performance and enhance insulin effects via inhibition of glucagon release from pancreatic $\alpha$-cells and stimulation of glucose uptake in adipocytes (Kharitonenkov et al. 2005).

\section{Circulating FGF21 levels in humans}

At present, very little is known about changes of serum FGF21 levels in humans. Two cross-sectional studies described increased FGF21 levels in patients with obesity and type 2 diabetes mellitus (Zhang et al. 2008, Chen et al. 2008). Furthermore, FGF21 levels correlated with several features of metabolic syndrome. Interestingly, FGF21 mRNA expression was also detected in subcutaneous adipose tissue and it positively correlated with circulating FGF21 levels (Zhang et al.
2008). Our preliminary data have shown that chronic malnutrition in patients with anorexia nervosa significantly decreases serum FGF21 levels relative to healthy normal-weight women (Dostálová et al. 2008).

\section{Conclusions and Perspectives}

FGF21 is a novel metabolic factor produced predominatly by the liver that exerts the unique role in the regulation of carbohydrate and lipid metabolism in the liver, adipose tissue and pancreas. FGF21 is tightly nutritionally-regulated in animal models and might represent a missing link in the adaptive response to longterm nutritional deprivation. FGF21 exhibits the therapeutic characteristics essential for an effective treatment of several components of metabolic syndrome including diabetes, dyslipidemia and obesity. Its administration in diabetic primates led to a sustainable improvement in glucose control without occurrence of hypoglycemia, a significant improvement of diabetic dyslipidemia and a mild weight loss without any significant side effects (Kharitonenkov et al. 2007). All of these characteristics make FGF21 a hot candidate for the treatment of patients with obesity and type 2 diabetes mellitus. Future studies are highly required to unravel whether the unique metabolic effects of FGF21 shown in rodents and primates are also present in humans.

\section{Conflict of Interest}

There is no conflict of interest.

\section{Acknowledgements}

Authors original studies cited in this review were supported by MZO VFN 2005.

\section{References}

BADMAN MK, PISSIOS P, KENNEDY AR, KOUKOS G, FLIER JS, MARATOS-FLIER E: Hepatic fibroblast growth factor 21 is regulated by PPAR $\alpha$ and is a key mediator of hepatic lipid metabolism in ketotic states. Cell Metab 5: 426-437, 2007.

CARBALLADA R, YASUO H, LEMAIRE P: Phosphatidylinositol-3 kinase acts in parallel to the ERK MAP kinase in the FGF pathway during Xenopus mesoderm induction. Development 128: 35-44, 2001.

CHEN WW, LI L, YANG GY, LI K, QI XY, ZHU W, TANG Y, LIU H, BODEN G: Circulating FGF-21 levels in normal subjects and in newly diagnose patients with Type 2 diabetes mellitus. Exp Clin Endocrinol Diabetes 116: $65-68,2008$.

CHOU CJ, HALUZIK M, GREGORY C, DIETZ KR, VINSON C, GAVRILOVA O, REITMAN ML: WY14,643, a peroxisome proliferator-activated receptor alpha (PPARalpha) agonist, improves hepatic and muscle steatosis and reverses insulin resistance in lipoatrophic A-ZIP/F-1 mice. J Biol Chem 277: 24484-24489, 2002. 
DEO DD, AXELRAD TW, ROBERT EG, MARCHESELLI V, BAZAN NG, HUNT JD: Phosphorylation of STAT-3 in response to basic fibroblast growth factor occurs through a mechanism involving platelet-activating factor, JAK-2, and Src in human umbilical vein endothelial cells. Evidence for a dual kinase mechanism. J Biol Chem 277: 21237-21245, 2002.

DOSTÁLOVÁ I, KAVÁLKOVÁ P, HALUZÍKOVÁ D, LACINOVÁ Z, MRÁZ M, PAPEŽOVÁ H, HALUZÍK M: Plasma concentrations of fibroblast growth factors 19 and 21 in patients with anorexia nervosa. $J$ Clin Endocrinol Metab 93: 3627-3632, 2008.

ESWARAKUMAR VP, LAX I, SCHLESSINGER J: Cellular signaling by fibroblast growth factor receptors. Cytokine Growth Factor Rev 16: 139-149, 2005.

GOETZ R, BEENKEN A, IBRAHIMI OA, KALININA J, OLSEN SK, ELISEENKOVA AV, XU C, NEUBERT TA, ZHANG F, LINHARDT RJ, YU X, WHITE KE, INAGAKI T, KLIEWER SA, YAMAMOTO M, KUROSU H, OGAWA Y, KURO-O M, LANSKE B, RAZZAQUE MS, MOHAMMADI M: Molecular insights into the klotho-dependent, endocrine mode of action of fibroblast growth factor 19 subfamily members. Mol Cell Biol 27: 3417-3428, 2007.

GUERRE-MILLO M, GERVOIS P, RASPÉ E, MADSEN L, POULAIN P, DERUDAS B, HERBERT JM, WINEGAR DA, WILLSON TM, FRUCHART JC, BERGE RK, STAELS B: Peroxisome proliferator-activated receptor alpha activators improve insulin sensitivity and reduce adiposity. J Biol Chem 275: 16638-16642, 2000.

HALUZÍK M, PAŘÍZKOVÁ J, HALUZÍK MM: Adiponectin and its role in the obesity-induced insulin resistance and related complications. Physiol Res 53: 123-9, 2004.

HAVEL PJ: Control of energy homeostasis and insulin action by adipocyte hormones: leptin, acylation stimulating protein, and adiponectin. Curr Opin Lipidol 13: 51-9, 2002.

HARMER NJ, ILAG LL, MULLOY B, PELLEGRINI L, ROBINSON CV, BLUNDELL TL: Towards a resolution of the stoichiometry of the fibroblast growth factor (FGF)-FGF receptor-heparin complex. J Mol Biol 339: 821834, 2004.

HOLT JA, LUO G, BILLIN AN, BISI J, MCNEILL YY, KOZARSKY KF, DONAHEE M, WANG DY, MANSFIELD TA, KLIEWER SA, GOODWIN B, JONES SA: Definition of a novel growth factor-dependent signal cascade for the suppression of bile acid biosynthesis. Genes Dev 17: 1581-1591, 2003.

HOUSA D, HOUSOVÁ J, VERNEROVÁ Z, HALUZÍK M: Adipocytokines and cancer. Physiol Res 55: 233-244, 2006.

HUANG X, YU C, JIN C, YANG C, XIE R, CAO D, WANG F, MCKEEHAN WL: Forced expression of hepatocytespecific fibroblast growth factor 21 delays initiation of chemically induced hepatocarcinogenesis. Mol Carcinog 45: 934-942, 2006.

IBRAHIMI OA, ZHANG F, HRSTKA SC, MOHAMMADI M, LINHARDT RJ: Kinetic model for FGF, FGFR, and proteoglycan signal transduction complex assembly. Biochemistry 43: 4724-4730, 2004.

INAGAKI T, CHOI M, MOSCHETTA A, PENG L, CUMMINS CL, MCDONALD JG, LUO G, JONES SA, GOODWIN B, RICHARDSON JA, GERARD RD, REPA JJ, MANGELSDORF DJ, KLIEWER SA: Fibroblast growth factor 15 functions as an enterohepatic signal to regulate bile acid homeostasis. Cell Metab 2: 217-225, 2005.

INAGAKI T, DUTCHAK P, ZHAO G, DING X, GAUTRON L, PARAMESWARA V, LI Y, GOETZ R, MOHAMMADI M, ESSER V, ELMQUIST JK, GERARD RD, BURGESS SC, HAMMER RE, MANGELSDORF DJ, KLIEWER SA: Endocrine regulation of the fasting response by PPAR $\alpha$-mediated induction of fibroblast growth factor 21. Cell Metab 5: 415-425, 2007.

ITO S, KINOSHITA S, SHIRAISHI N, NAKAGAWA S, SEKINE S, FUJIMORI T, NABESHIMA YI: Molecular cloning and expression analyses of mouse $\beta$ klotho, which encodes a novel Klotho family protein. Mech Dev 98: 115-119, 2000.

ITOH N, ORNITZ DM: Evolution of the Fgf and Fgfr gene families. Trends Genet 20: 563-569, 2004.

KHARITONENKOV A, SHIYANOVA TL, KOESTER A, FORD AM, MICANOVIC R, GALBREATH EJ, SANDUSKY GE, HAMMOND LJ, MOYERS JS, OWENS RA, GROMADA J, BROZINICK JT, HAWKINS ED, WROBLEWSKI VJ, LI DS, MEHRBOD F, JASKUNAS SR, SHANAFELT AB: FGF-21 as a novel metabolic regulator. $J$ Clin Invest 115: 1627-1635, 2005. 
KHARITONENKOV A, WROBLEWSKI VJ, KOESTER A, CHEN YF, CLUTINGER CK, TIGNO XT, HANSEN BC, SHANAFELT AB, ETGEN GJ: The metabolic state of diabetic monkeys is regulated by fibroblast growth factor-21. Endocrinology 148: 774-781, 2007.

KONTARIDIS MI, LIU X, ZHANG L, BENNETT AM: Role of SHP-2 in fibroblast growth factor receptor-mediated suppression of myogenesis in C2C12 myoblasts. Mol Cell Biol 22: 3875-3891, 2002.

KUROSU H, CHOI M, OGAWA Y, DICKSON AS, GOETZ R, ELISEENKOVA AV, MOHAMMADI M, ROSENBLATT KP, KLIEWER SA, KURO-O M: Tissue-specific expression of $\beta$ Klotho and fibroblast growth factor (FGF) receptor isoforms determines metabolic activity of FGF19 and FGF21. J Biol Chem 282: 26687-26695, 2007.

LUNDÅSEN T, GÄLMAN C, ANGELIN B, RUDLING M: Circulating intestinal fibroblast growth factor 19 has a pronounced diurnal variation and modulates hepatic bile acid synthesis in man. $J$ Intern Med 260: 530-536, 2006.

LUNDÅSEN T, HUNT MC, NILSSON LM, SANYAL S, ANGELIN B, ALEXSON SE, RUDLING M: PPARalpha is a key regulator of hepatic FGF21. Biochim Biophys Res Commun 360: 437-440, 2007.

MEMON RA, TECOTT LH, NONOGAKI K, BEIGNEUX A, MOSER AH, GRUNFELD C, FEINGOLD KR: Upregulation of peroxisome proliferator-activated receptors (PPAR-alpha) and PPAR-gamma messenger ribonucleic acid expression in the liver in murine obesity: troglitazone induces expression of PPAR-gammaresponsive adipose tissue-specific genes in the liver of obese diabetic mice. Endocrinology 141: 4021-4031, 2000.

MOHAMMADI M, OLSEN SK, GOETZ R: A protein canyon in the FGF-FGF receptor dimer selects from an à la carte menu of heparan sulfate motifs. Curr Opin Struct Biol 15: 506-516, 2005.

MOYERS JS, SHIYANOVA TL, MEHRBOD F, DUNBAR JD, NOBLITT TW, OTTO KA, REIFEL-MILLER A, KHARITONENKOV A: Molecular determinants of FGF-21 activity-synergy and cross-talk with PPARgamma signaling. J Cell Physiol 210: 1-6, 2007.

NICHOLES K, GUILLET S, TOMLINSON E, HILLAN K, WRIGHT B, FRANTZ GD, PHAM TA, DILLARDTELM L, TSAI SP, STEPHAN JP, STINSON J, STEWART T, FRENCH DM: A mouse model of hepatocellular carcinoma: ectopic expression of fibroblast growth factor 19 in skeletal muscle of transgenic mice. Am J Pathol 160: 2295-2307, 2002.

NISHIMURA T, NAKATAKE Y, KONISHI M, ITOH N: Identification of a novel FGF, FGF-21, preferentially expressed in the liver. Biochim Biophys Acta 1492: 203-206, 2000.

OGAWA Y, KUROSU H, YAMAMOTO M, NANDI A, ROSENBLATT KP, GOETZ R, ELISEENKOVA AV, MOHAMMADI M, KURO-O M: BetaKlotho is required for metabolic activity of fibroblast growth factor 21 . Proc Natl Acad Sci USA 104: 7432-7437, 2007.

ORNITZ DM, ITOH N: Fibroblast growth factors. Genome Biol 2: REVIEWS3005, 2001.

PELECH SL, OLWIN BB, KREBS EG: Fibroblast growth factor treatment of Swiss 3T3 cells activates a subunit S6 kinase that phosphorylates a synthetic peptide substrate. Proc Natl Acad Sci USA 83: 5968-5972, 1986.

SHEPHERD PR, KAHN BB: Glucose transporters and insulin action - implications for insulin resistance and diabetes mellitus. $N$ Engl J Med 341: 248-257, 1999.

SHIMADA T, HASEGAWA H, YAMAZAKI Y, MUTO T, HINO R, TAKEUCHI Y, FUJITA T, NAKAHARA K, FUKUMOTO S, YAMASHITA T: FGF-23 is a potent regulator of vitamin D metabolism and phosphate homeostasis. J Bone Miner Res 19: 429-435, 2004.

SUZUKI M, UEHARA Y, MOTOMURA-MATSUZAKA K, OKI J, KOYAMA Y, KIMURA M, ASADA M, KOMIKURAMOCHI A, OKA S, IMAMURA T: $\beta$ Klotho is required for fibroblast growth factor (FGF) 21 signaling through FGF receptor (FGFR) 1c and FGFR3c. Mol Endocrinol 22: 1006-1014, 2008.

TOMLINSON E, FU L, JOHN L, HULTGREN B, HUANG X, RENZ M, STEPHAN JP, TSAI SP, POWELLBRAXTON L, FRENCH D, STEWART TA: Transgenic mice expressing human fibroblast growth factor-19 display increased metabolic rate and decreased adiposity. Endocrinology 143: 1741-1747, 2002.

WANG H, QIANG L, FARMER SR: Identification of a domain within peroxisome proliferator-activated receptor gamma regulating expression of a group of genes containing fibroblast growth factor 21 that are selectively repressed by SIRT1 in adipocytes. Mol Cell Biol 28: 188-200, 2008. 
WENTE W, EFANOV AM, BRENNER M, KHARITONENKOV A, KÖSTER A, SANDUSKY GE, SEWING S, TREINIES I, ZITZER H, GROMADA J: Fibroblast growth factor-21 improves pancreatic beta-cell function and survival by activation of extracellular signal-regulated kinase 1/2 and Akt signaling pathways. Diabetes 55: 2470-2478, 2006.

WINEGAR DA, BROWN PJ, WILKISON WO, LEWIS MC, OTT RJ, TONG WQ, BROWN HR, LEHMANN JM, KLIEWER SA, PLUNKET KD, WAY JM, BODKIN NL, HANSEN BC: Effects of fenofibrate on lipid parameters in obese rhesus monkeys. J Lipid Res 42: 1543-1551, 2001.

ZHANG X, IBRAHIMI OA, OLSEN SK, UMEMORI H, MOHAMMADI M, ORNITZ DM: Receptor specificity of the fibroblast growth factor family. The complete mammalian FGF family. J Biol Chem 281: 15694-15700, 2006.

ZHANG X, YEUNG DC, KARPISEK M, STEJSKAL D, ZHOU ZG, LIU F, WONG RL, CHOW WS, TSO AW, LAM KS, XU A: Serum FGF21 levels are increased in obesity and are independently associated with the metabolic syndrome in humans. Diabetes 57: 1246-1253, 2008. 